J. Clin. Chem. Clin. Biochem.

Vol. 20, 1982, pp. $451-455$

\title{
Determination of the Molecular Weight of $\alpha$-Amylase, as the Enzyme-Inhibitor Complex, using Thin Layer Gel Filtration on Sephadex
}

\author{
By J. Kamarýt, J. Zemek and L: Kuniak \\ Pediatric Research Institute (Head: As. Prof. Dr. M. Stavratjev, DrSc.), Brno, ČSSR and \\ Institute of Chemistry, Slovak Academy of Sciences (Head: Ing. M. Repás, CSc.) Bratislava, ČSSR
}

(Received July 30/December 29, 1981)

\begin{abstract}
Summary: Thin layer gel filtration on Sephadex was performed as a simple method for recognition of the small molecular weight differences of human $\alpha$-amylases from different sources. Activity was located with dry chromogenic substrate, using a replica technique. Undesirable interaction between the gel matrix and substrate binding sites on the enzyme, which causes an anomalous decrease in the migration rate of the enzyme protein, was suppressed by preincubation of the enzyme with appropriate inhibitor. Gradual masking of substrate binding sites of the enzyme by increasing concentrations of amylase inhibitor resulted in two distinct migration rates for the enzyme in thin layer gel filtration. This suggests the existence of two substrate binding sites in the enzyme molecule. Together with thin layer gel affinity chromatography on a mixture of Sephadex and ConA-Sepharose, the method yielded useful data on the molecular weight of amylase and its glycosylated forms and served as a valuable tool for the differential diagnosis of macroamylasaemia.
\end{abstract}

\section{Bestimmung des Molekulargewichtes von $\alpha$-Amylase als Enzym-Inhibitor-Komplex mit Dünnschichtgelfiltration an Sephadex}

Zusammenfassung: Die Dünnschichtgelfiltration an Sephadex-Gel wurde für dạs einfache Erkennen der geringen Molekulargewichtsdifferenzen der menschlichen $\alpha$-Amylasen verschiedener Herkunft verwendet. Die Enzymaktivitäten wurden mit einem chromogenen Substrat und nachfolgender „Replica-Technik“ lokalisiert. Die unerwünschte Interaktion zwischen den Substratbindungsstellen von Amylase und Gel-Matrix, welche die anomale, reduzierte Beweglichkeit des Enzymproteins im Laufe der Entwicklung des Chromatogramms verursachte, wurde durch die Vorinkubation der Amylase mit Inhibitor unterdrückt. Die schrittweise Maskierung der Substratbindungsstellen des Enzyms durch steigende Sättigung mit dem Amylase-Inhibitor resultierte in zwei verschiedenen Beweglichkeiten des Enzym-Moleküls während der Entwicklung des Čhromatogramms, was die Existenz von zwei Substratbindungsstellen dès Amylāse-Moleküls andeutet. Die Methode der Dünnschichtgelfilträtion zusammen mit Dünnschichtgel-Affinitätschromatographie an Sephadex und Con A-Sepharose-Gèl führt zu nützlichen Angaben über das unterschiedliche Molekulargewicht von Amylase und ịrer glykosylierten Formen, und die Methode zeigt sich auch als ein wertvolles Verfahren für dịe Differentialdiagnose der Makroamylasämie.

\section{Introduction}

The $\alpha$-amylases ( $\alpha$-1,4-glucan 4-glucanohydrolase, E.C. 3.2.1.1) from salivary glands and pancreas, which may be distinguished by means of various analytical techniques, particularly by electrophoresis, are very similar enzymes. Comparison of the peptide maps of both amylases shows more similarities than differences (1). Also efforts to show immunological differences between salivary and pancreatic amylase remain unsuccessful (2). Salivary and pancreatic amylase cannot be differentiated with amylase antibodies; the antigenicities of the two isoenzymes are completely identical (3). The biosynthesis of both isoamylases is controlled by two separated gene loci AMY 1 and AMY 2, which are closely linked on chromosome 1 $(4,5)$. The molecular weights of salivary and pancreatic amylases are slightly different. This may be due to posttranscriptional glycosylation especially of the enzyme molecules originating from salivary glands (6). It is 
possible that the different renal clearances of these two isoamylases are a consequence of these molecular alterations. The salivary amylase of the blood passes through the glomeruli with roughly the half velocity of the pancreatic enzyme (7). The molecular weight estimation of amylases yields useful data for the characterization of enzymes originating from various sources and for the diagnosis of macroamylasaemias.

Thin layer gel filtration on Sephadex, commonly used for the molecular weight determination of proteins, represents a simple and versatile method. Unfortunately, the $\alpha$-amylase interacts with the Sephadex matrix, so that the migration rate of the enzyme is decreased during chromatography and the apparent molecular weights are lower than those obtained by other techniques $(8,9)$. Using Sephadex G-100, Minamiura et al. estimated the molecular weight of $\alpha$-amylase in human urine to be less than $12000(10)$. The enzyme was adsorbed on this gel so strongly that the elution volume was larger than that of lysozyme. Similarly on columns of Bio-Gel P-100 and P-150 human and rat amylase was eluted much later than proteins of approximately the same molecular weight, even though the anomalous retardation was unexpected since Bio-Gel does not simulate the natural substrate for amylase $(11,12)$. These troubles may be avoided and thin layer gel filtration on Sephadex used successfully, if the substrate binding sites of the enzyme are masked by an appropriate amylase inhibitor and a simple and sensitive detection technique for the residual enzyme activity is used.

\section{Materials and Methods}

The $\alpha$-amylases of blood serum, urine, saliva, duodenal juice, and breast milk were analyzed. Only fresh biological material was examined. The samples were diluted to the catalytic concentration range 200-500 U/1 (3.3-8.4 $\mu \mathrm{kat} / \mathrm{l})$; but the serum from the individual with macroamylasaemia was not diluted, because dilution causes dissociation of the macroamylase complex. Thin layer gel filtration was performed with the apparatus from Pharmacia Fine Chemicals, Uppsala. For the required separation efficacy, the standard plates $20 \times 20 \mathrm{~cm}$ or $20 \times 40 \mathrm{~cm}$ were used. Sephadex G-100 and G-150 Superfine grade served as the stationary phase (thickness of layer $0.6 \mathrm{~mm}$ ). The mobile phase was Tris/HCl buffer $100 \mathrm{mmol} / \mathrm{l}$, pH 8.0. After overnight equilibration at an angle of $10^{\circ}, 10 \mu \mathrm{l}$ biological fluid samples of enzyme catalytic concentration $200-500 \mathrm{U} / 1$ were applied to the gel layer. Reference marker proteins for calculation of relative migration distance were applied simultaneously to the layer. After 4-7 hours development (depending on the plate size, $20 \times 20$ or $20 \times 40 \mathrm{~cm}$ respectively) at an angle of $15^{\circ}$ and at room temperature, the chromatograms were covered with dry powdered chromogenic substrate (cross-linked blue starch polymer, product of Slovakofarma Hlohovec, CSSR) (75 mg per $20 \times 20 \mathrm{~cm}$ plate) and incubated at $37^{\circ} \mathrm{C}$ for the time necessary for the enzyme spots to become visible. $\alpha$-Amylase hydrolyzes polymer into water-soluble blue starch fragments. The replica technique was then used for preparing permanent records. The water-soluble blue starch fragments were transferred from the gel layer to filter paper Whatman $3 \mathrm{MM}$ by a contact with the gel for 1 minute. The paper chromatogram was then dried at $100^{\circ} \mathrm{C}$ for 10 minutes. The replica with reference proteins was stained with Coomassie Brilliant Blue R-250 (Serva Biochemica, Heidelberg). The $\alpha$-amylase-inhibitor complex was separated on thin layer gels of Sephadex under the above described conditions. Increasing concentrations $(5.4-540 \mu \mathrm{g})$ of inhibitor protein were added to $450 \mathrm{mU}$ of enzyme in $1 \mathrm{ml}$. The $\alpha$-amylase inhibitor isolated from potatoes is a protein with a relatively low molecular weight of about 15000-17000 (product of Institute of Chemistry, Slovak Academy of Sciences, Bratislava, ('SSR) and it exhibits a higher degree of inhibition against salivary amylase $(83 \%)$ ) than against the pancreatic enżyme $(62 \%)$.

\section{Results and Discussion}

The suitability of the replica detection technique using chromogenic substrate for the visualisation of amylase activities (after development on thin layer gels of Sephadex) is demonstrated by the separation of the enzyme from human milk (fig. 1). The chromatogram actually the paper reprint of the thin layer gel chromatogram - of various dilutions of one human milk sample was evaluated reflectometrically. The relationship between gradually increasing amylase activities, spot size and its colour intensity expressed in integration. units is plotted in figure 2. The thin layer gel filtration revealed two dinstinct breast milk amilase spots, differing in their molecular weights. Similarly, as in the case of salivary amylase, a part of the breast milk amylase is glycosylated.

Masking the substrate binding sites of $\alpha$-amylase by increasing concentrations of appropriate inhibitor gradually diminishes the anomalous binding effect of $\alpha$-amylase to Sephadex and contributes to the normalization of the migration rate of the enzyme protein

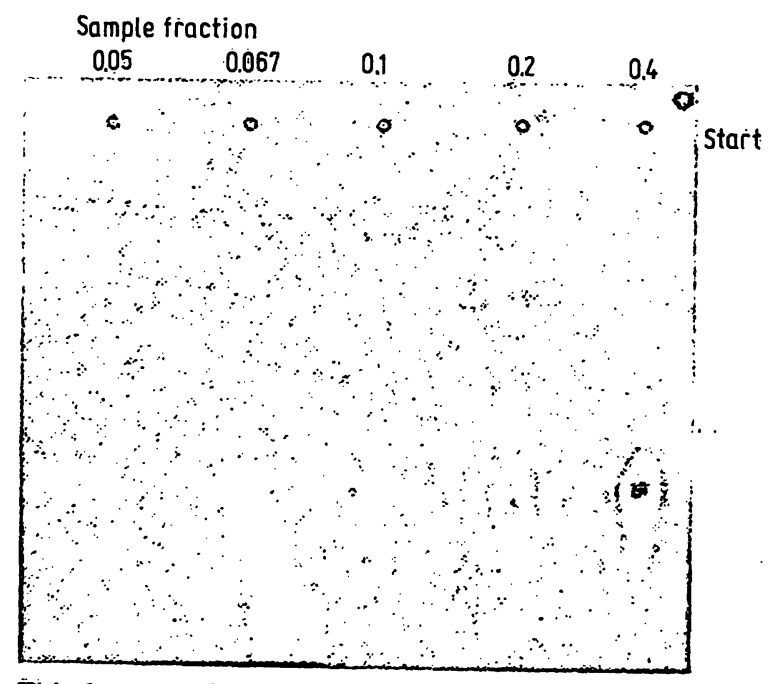

Fig. 1. Thin layer gel filtration of various dilutions of human milk amylase on Sephadex G-100 Superfine. The volume fractions of the originally undiluted milk sample $(2280$ U/1) are given. Thin-layer plate: $20 \times 20 \mathrm{~cm}$. Layer thickness: $0.6 \mathrm{~mm}$. Time: $5 \mathrm{~h}$. Angle: $15^{\circ}$. Buffer: $100 \mathrm{mmol} / 1$ - Tris/ $\mathrm{HCl}, \mathrm{pH}$ 8:0 containing $0.2 \mathrm{~g} / \mathrm{l}$ sodium azide. Two distinct amylase spots are evident (sample volumes $10 \mu \mathrm{l}$ ). The glycosylated amylase shows the.faster migration rate. 
(fig. 3). The uninhibited residual enzyme activity is sufficient to be detected during prolonged incubation with chromogenic substrate.

Thin layer gel filtration on Sephadex permits the estimation of the relative small molecular weight differences between salivary and pancreatic amylases. Part

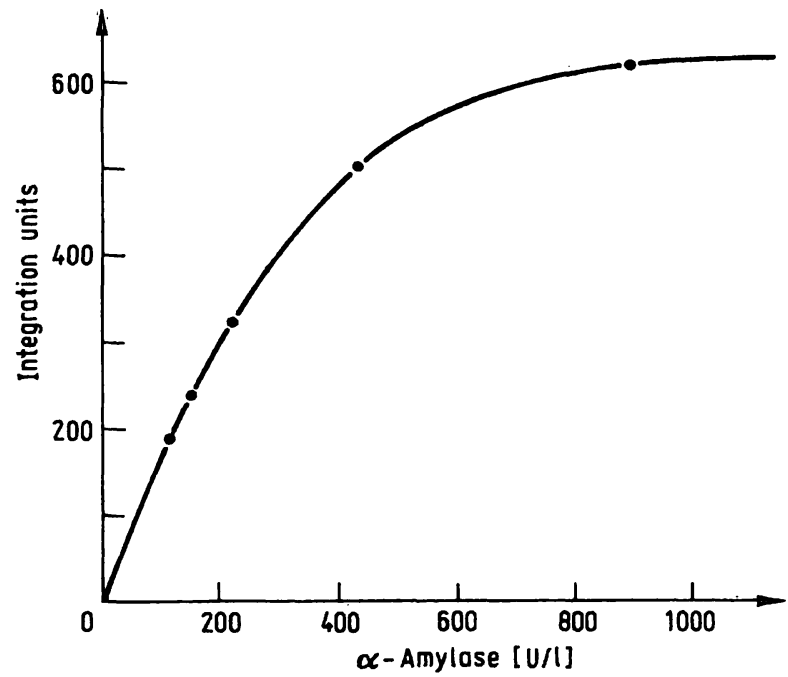

Fig. 2. The relationship between increasing amylase activities of gradually diluted human milk sample and integration units obtained by reflectometric scanning (at $600 \mathrm{~nm}$ ) of previous chromatogram. The sum of gly cosylated and unglycosylated enzyme integration units was plotted.

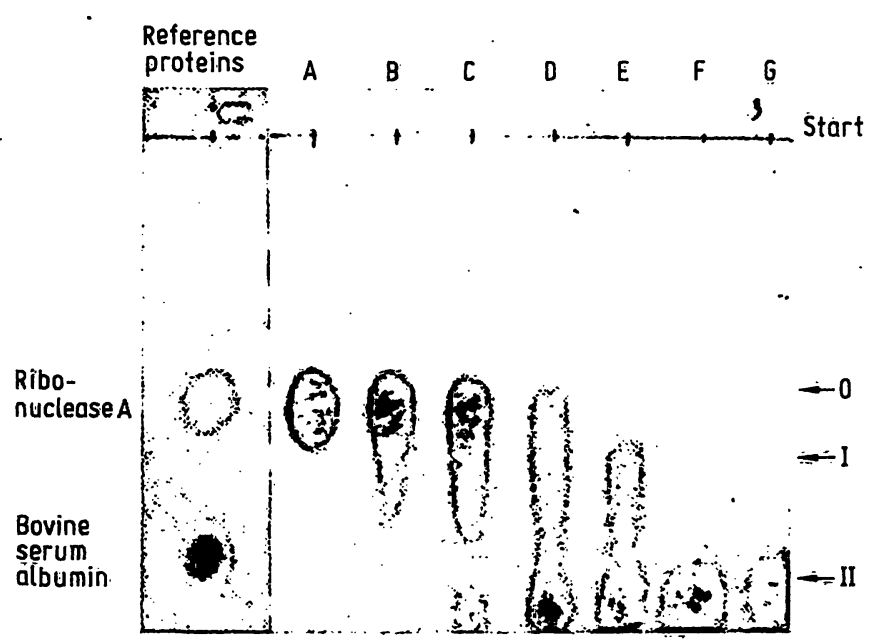

Fig. 3. Masking of substrate binding sites of amylase molecules (urine amylase) with gradually increasing concentrations of amylase inhibitor.

$A=$ urine sample without inhibitor;

$\mathrm{B}=$ urine with $5.4 \mu \mathrm{g}$;

$\mathrm{C}=16.2 \mu \mathrm{g}$

$\mathrm{D}=32.4 \mu \mathrm{g}$;

$E=54.0 \mu \mathrm{g}$

$\mathrm{F}=270.0 \mu \mathrm{g}$

$\mathrm{G}=540.0 \mu \mathrm{g}$ of inhibitor protein to $450 \mathrm{mU}$ of enzyme in $1 \mathrm{ml}$.

$\mathbf{R P}=$ reference proteins:

RIB A = ribonuclease A, $M_{\mathrm{r}} 13700$

$\mathrm{BSA}=$ bovine serum albumin, $M_{\mathrm{r}} 67000$

0 - indicates the uninhibited amylase spot migration rate.

I - the first step and

II - the second step of enzyme substrate binding site masking with amylase inhibitor. of the salivary amylase is glycosylated and therefore has a higher molecular weight. Pancreatic amylase does not show such a high degree of posttranscriptional glycosylation. Using amylase inhibitor for masking the enzyme binding sites permits the estimation of the real molecular weight by thin layer gel filtration on Sephadex. Separation of the salivary amylase of saliva and the pancreatic amylase of duodenal juice, with or without previous preincubation with amylase inhibitor, are shown in figure 4; the small molecular weight differences between the various isoamylases originating from both glands are expressed.

Thin layer gel affinity chromatography of human breast milk on a mixture of Sephadex G-150 and Con A-

Sepharose (2:1) revealed two isoamylases differing in the amount of sugar residues (fig. 5). The carbohydrate rich amylase showed a considerably retarded migration due to the interaction with the incorporated affinity ligand concanavalin $\mathrm{A}$. The isoamylase with low carbohydrate content showed the usual migration rate.

Takeuchi similarly separated the salivary amylases by means of concanavalin A Sepharose chromatography into two fractions. The adsorbed fraction with affinity for concanavalin A showed a higher carbohydrate content than the unadsorbed one without affinity for con-
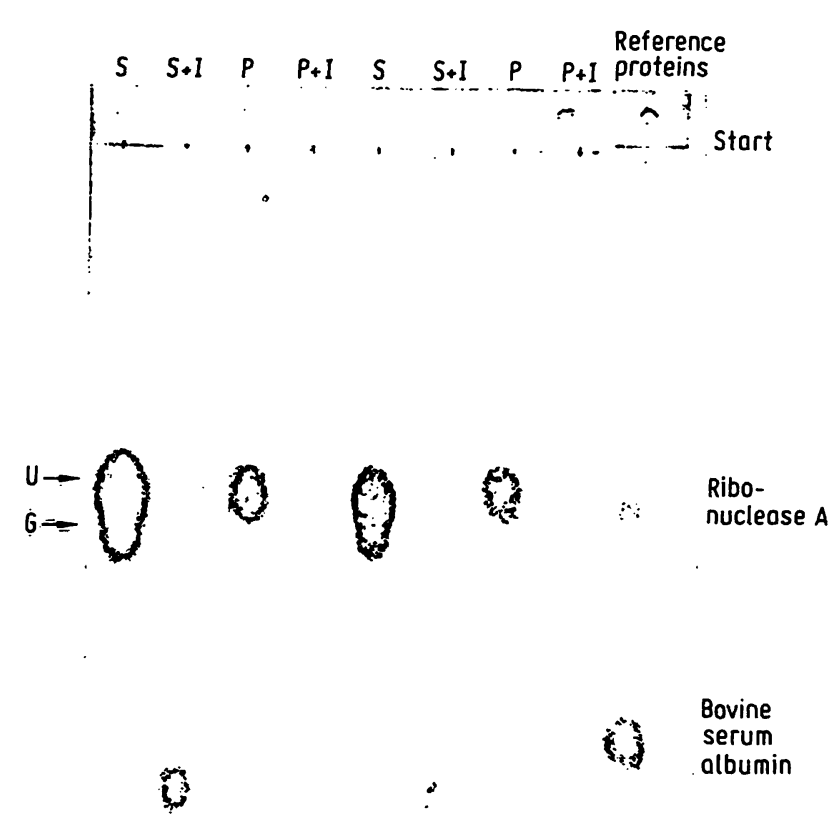

\section{r}

Fig. 4. The molecular weight differences between salivary (S) and pancreatic $(P)$ amylase from saliva and duodenal juice. Each sample, native and inhibited $(+I=$ with inhibitor) was doubled in order to avoid migration irregularities. Two salivary amylase families are evident: unglycosylated $(U)$ and glycosylated $(G)$ as in human milk. The pancreatic amylase from duodenal juice did not show this phenomenon.

Thin-layer plate: $20 \times 40 \mathrm{~cm}$. Gel: Sephadex G-150 Superfine. Layer thickness: $0: 6 \mathrm{~mm}$. Time: $6 \mathrm{~h} 35 \mathrm{~min}$. Angle: $15^{\circ}$. 


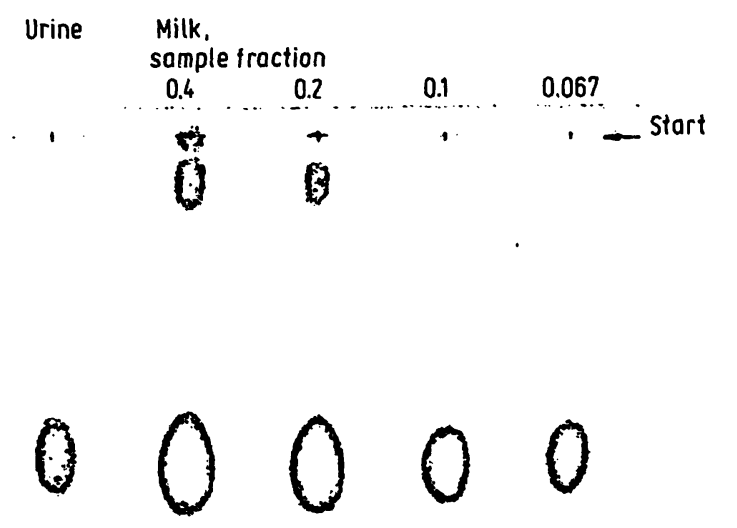

Fig. 5. Thin layer gel affinity chromatography of human milk amylase. $U=$ urine from healthy control; $M=$ human milk samples with indicated dilution coefficients. The glycosylated amylase revealed decreased enzyme activity and reduced migration rate due to the interaction with the affinity ligand concanavalin $\mathrm{A}$.

Thin-layer plate: $20 \times 20 \mathrm{~cm}$. Gel: Sephadex G-150 Superfine and Con A-Sepharose (2:1). Layer thickness: $0.6 \mathrm{~mm}$. Time: 5 h 30 min. Angle: $15^{\circ}$. Buffer: Tris/ $\mathrm{HCl} 100$ $\mathrm{mmol} / 1, \mathrm{pH} 8.0$

canavalin $\mathrm{A}$. The data indicated that the salivary amylase that binds to concanavalin $\mathrm{A}$ is that with the higher molecular weight (3). The isoamylases in breast milk and saliva showed identical electrophoretic mobility. Isoelectric focusing also revealed four identical bands in breast milk and saliva: one main band with a pl of 6.4 and three weaker bands with pI of 5.9, 5.6 and 5.4 respectively (own unpublished results).

The use of amylase inhibitor in combination with an enzyme detection technique with powdered chromogenic substrate makes it possible to easily distinguish the macroamylase, which is usually the complex of serum amylase with the large globulins preventing clearance by the kidney (fig. 6 ). The binding substance evidently masks the binding sites of a portion of the blood serum amylase. The migration distances of unhibited and inhibited macroamylase during thin layer gel filtration are the same. Hence it follows that the binding sites of the macroamylase are occupied by the binding substance - and thus do not interact with the matrix of the gel. After the preincubation of macroamylasaemic blood serum with amylase inhibitor, the originally slowly migrating portion of normal amylase exhibited a migration distance corresponding to the correct molecular weight.

The detection technique using the dry powdered chromogenic substrate followed by the replica technique was the key to the successful application of thin layer gel filtration on Sephadex or thin layer gel affinity chromatography. The technique makes it possible to follow the development of blue colour due to the $\alpha$-amylase action in the gel layer during the incubation period.
The anomalous migration rate of amylase on Sephadex gel and thus the impossibility of using this method for molecular weight determination was observed earlier by several authors. Wilding (9) ascertained by means of gel filtration on Sephadex that the amylase was eluted from the column at a point which suggests that amylase has an apparent molecular weight of less than 20000 . Mutzbauer et al. (13) using the value of the partial specific volume calculated from the amino acid composition gives a value 55200 for the molecular weight of human salivary amylase. The studies of Keller et al. (6) yielded a molecular weight of salivary amylase of 61900 and 56100 . Stiefel et al. (1) reported a molecular weight of 54000 for human pancreatic amylase. Flodin suggested that the anomalous behaviour of $\alpha$-amylase in gel filtration on Sephadex is due to the interaction between the enzyme and the gel matrix. He claims this is a reasonable hypothesis in view of the similarity in structure of starch and dextran (8). According to Takeuchi, chromatography of mammalian amylases on Sephadex G-100 and Sepharose

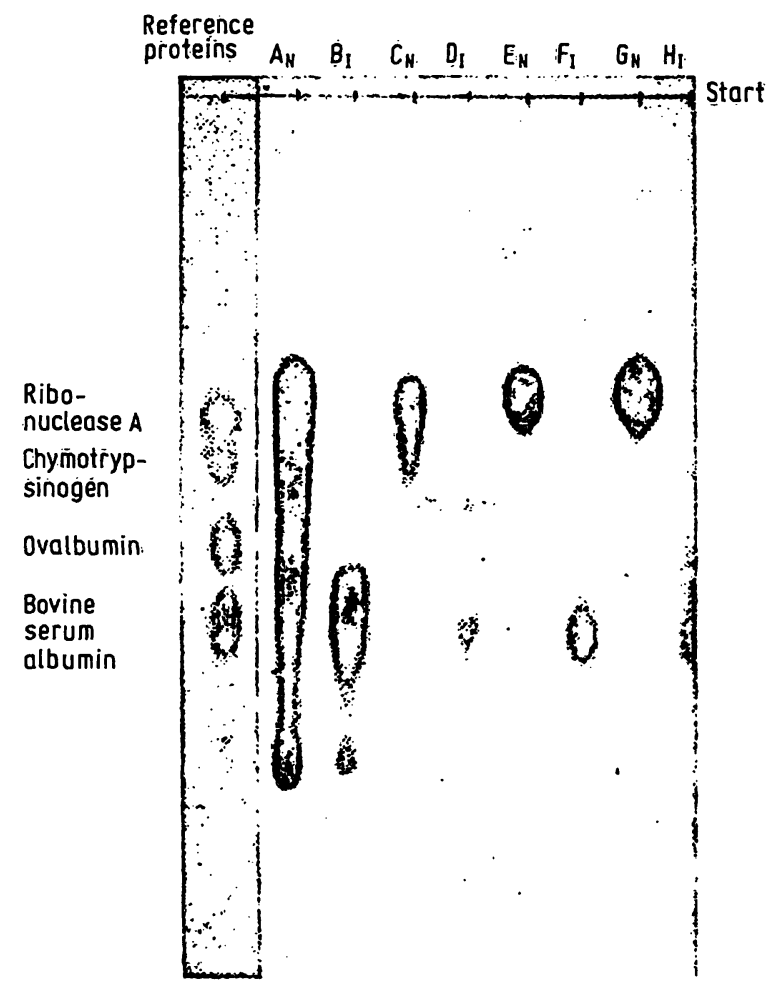

Fig. 6. Thin layer gel filtration of the serum amylase from a . subject with macroamylasaemia.

$A=$ native undiluted serum;

B = macroamylasaemic serum preincubated with àmylase inhibitor;

$C$ and $D=3$ fold diluted macroamylasaemic serum native (N) and inhibited (I);

$E$ and $F$ = macroamylasaemic urine native and inhibited; $G$ and $H \equiv$ urine from healthy control native and inhibited.

$\mathrm{RP}=$ reference proteins:

ribonucleàsè A, $M_{\mathrm{r}} 13.700$;

chymotrypsinogen A, $M_{\mathrm{r}} 25000$;

ovalbumin, $M_{\mathrm{r}} 43000$;

bovine serum albumin, $M_{\mathrm{r}} 67.000$.

Thin-layer plate: $20 \times 40 \mathrm{~cm}$. Gel: Sephadex G-150

superfine. Layer thickness: $0.6 \mathrm{~mm}$. Time: $6 \mathrm{~h} 50 \mathrm{~min}$. Angle: $15^{\circ}$. Buffer: Tris/HCl $100 \mathrm{mmbi} / 1, \mathrm{pH} 8.0$. 
4B is affinity chromatography, not gel filtration (3). The amylase appears to be held on the columns by interactions other than simple gel filtration effects (11). Minamiura et al. supposed that the very strong adsorption of $\alpha$-amylase on Sephadex may be due to tryptophan and/or tyrosine residue(s) protruding from the enzyme molecule (10). The amylases are rich in hydroxyamino acids or their amides and have a high capacity for hydrogen bonding both intramolecularly to give a particularly compact structure, and extramolecularly, with materials such as Sephadex and Bio-Gel (12). The interaction of the amylase with the dextran matrix, which causes the decreased migration rate during thin layer gel filtration on Sephadex, can be diminished by means of the preincubation of enzyme-containing biological fluid with inhibitor before the sample is applied to the gel layer. The increasing concentrations of inhibitor influence the enzyme migration rate during gel-layer development in two steps. In the first step it seems that one substrate binding site of the enzyme is masked, and the molecules behave with an apparent molecular weight of about 34000 . In the second step during further inhibitor saturation the second enzyme binding site is masked and the migration rate of the complex enzyme-inhibitor accelerates dramatically and corresponds to the expected migration rate for a component of molecular weight 70000-75 000 (fig. 7). Thus our findings agree with these of Loyter et al. who supposed the existence of two substrate binding sites in pancreatic amylase (14). On the other hand Móra et al. consider three independent binding sites (15). The preincubation of biological samples to be analyzed before thin layer gel filtration with amylase inhibitor enables the estimation of the differences in molecular weight of $\alpha$-amylases originating from various glands and tissues and offerers a particularly simple assay for the differential diagnosis of macroamylasaemia. The findings of Kitamura et al. (16) that the amylase binding substance of the macroamylase is

\section{References}

1. Stiefel, D. J. \& Keller, P. J. (1973) Biochim. Biophys. Acta $302,345-361$.

2. Karn, R. C., Rosenblum, B. B., Ward, J. C., Merritt, A. D. \& Shulkin, J. D. (1974) Biochem. Genet. 12, 485-499.

*3. Takeuchi, T. (1979) Clin. Chem. 25, 1406-1410.

4. Kamarýt, J., Adámek, R. \& Vrba, M. (1971) Humangenetik $11,213-220$.

5. Merritt, A. D., Lovrien, E. W., Rivas, M. L. \& Conneally, P. M. (1973) Am. J. Hum. Genet. 25, 523-538.

6. Keller, P. J., Kauffman, D. L., Allan, B. J. \& Williams, B. L. (1971) Biochemistry 10,4867-4874.

7. Kamarýt, J. (1969) Z. Klin. Chem. Klin. Biochem. 7, 51-52.

8. Flodin, P. (1962) Dextran gels and their application in gel filtration. AB Pharmacia, Uppsala.

9. Wilding, P. (1963) Clin. Chim. Acta 8, 918-924.

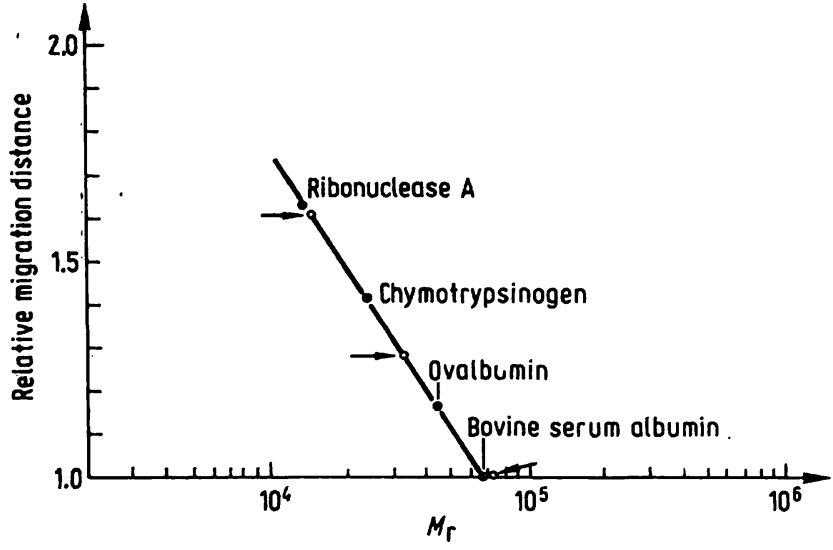

Fig. 7. Relationship between migration distance (relative to bovine serum albumin) and $\log M_{\mathrm{r}}$ for some standard proteins (the black circles).

The open circles with arrows:

top - spot of unhibited urine amylase (apparent $M_{\mathbf{r}}$ similar to that of ribonuclease A);

middle - spot of urine amylase with incompletely masked substrate binding sites of the enzyme with inhibitor (apparent $M_{\mathrm{r}} 34000$ );

bottom - the migration rate of the complex amylaseinhibitor with completely masked substrate binding sites of the enizyme $\left(M_{\mathrm{r}} 75000\right)$.

Thin-layer plate: $20 \times 40 \mathrm{~cm}$. Gel: Sephadex G-150 Superfine. Layer thickness: $0.6 \mathrm{~mm}$. Time: $6 \mathrm{~h} 50 \mathrm{~min}$. Angle: $15^{\circ}$. Migration distance for bovine serum albumin was $260 \mathrm{~mm}$. Buffer: Tris/HCl $100 \mathrm{mmol} / 1, \mathrm{pH} 8.0$.

capable of binding to the substrate-binding site agree with our present results obtained by thin layer gel filtration on Sephadex.

Thin layer gel filtration of amylase and amylaseinhibitor complex, accompanied by the appropriate detection of the enzyme activities with chromogenic substrate, represents a simple and reliable method permitting determination of enzyme molecular weight and providing an insight into the catalytic mechanism of the enzyme. The method gives results comparable with those obtained with other more complicated and more time consuming procedures.
10. Minamiura, N., Kimura, Y., Tsujino, K. \& Yamamoto, T. (1974) J. Biochem. 77, 163-169.

11. Allan, B. J., Zager, N. I. \& Keller, P. J. (1970) Arch. Biochem. Biophys. 136, 529-540.

12. Kauffman, D. L., Zager, N., Cohen, E. \& Keller, P. J. (1970), Arch. Biochem. Biophys. 137, 325-339.

13. Mutzbauer, H. \& Schulz, G. V. (1965) Biochim. Biophys. Acta 102, 526-532.

14. Loyter, A. \& Schramm, M. (1966) J. Biol. Chem. 241, 2611-2617.

15. Móra, S., Simon, I. \& Elödi, P. (1974) Mol. Cell. Biochem 4., $205-209$.

16. Kitamura, T., Yoshida, K., Ehara, M. \& Akedo, H. (1977) Gastroenterology 73, 46-51.
J. Kamarýt, Ph. D. Pediatric Research Institute Cernopolni 9 CS.66262 Brno 
